\title{
Increased numbers of dendritic cells in the bronchial mucosa of atopic asthmatic patients: downregulation by inhaled corticosteroids
}

\author{
G. M. MÖLLER*†, S. E. OVERBEEK*, C. G. VAN HELDEN-MEEUWSEN $\dagger$, \\ J. M. W. VAN HAARST†, E. P. PRENS $\uparrow$, P. G. MULDER $†$, D. S. POSTMA $\S$ and \\ H. C. HOOGSTEDEN* \\ *Departments of Pulmonary Diseases, †Immunology and $\$$ Epidemiology and Biostatistics, Erasmus University and \\ University Hospital Dijkzigt, Rotterdam, and §Department of Pulmonary Diseases, University Hospital Groningen, the \\ Netherlands
}

\begin{abstract}
Summary
Background Dendritic cells (DC) are the most potent antigen-presenting cells (APC) and stimulators of T cells. Dendritic cells are also likely to be essential for the initiation of allergic immune responses in the lung. However, there are not many data on the presence of dendritic cells in the airways of patients with atopic asthma and on the effects of corticosteroid-treatment on such dendritic cells.

Objective We investigated the distribution of dendritic cells in the bronchial epithelium and mucosa of 16 non-smoking atopic asthmatic patients and eight healthy control subjects using detailed immunohistochemistry (CD1a, HLA-DR, L25 as markers for dendritic cells).

Methods Eleven asthmatics were treated for 2.5 years with bronchodilators only and five with bronchodilators and inhaled beclomethasone dipropionate (BDP), $800 \mu \mathrm{g}$ daily. The patients were randomly sampled from a double-blind multicentre study.

Results There were higher numbers of CD1a ${ }^{+} \mathrm{DC}(P=0.003), \mathrm{L}^{2} 5^{+} \mathrm{DC}(P=0.002)$ and HLA-DR expression $(P=0.042)$ in the bronchial mucosa of asthmatic patients compared with healthy controls. After 2.5 years of treatment, we found a significant increase in flow expiratory volume in 1 second $\left(\mathrm{FEV}_{1}\right)(P=0.009)$ and a significant decrease in hyperresponsiveness $\left(\mathrm{PC}_{20}\right.$ histamine $)(P=0.013)$ in the corticosteroid group $(n=5)$ compared with the bronchodilator group $(n=11)$. This clinical improvement in the corticosteroid-treated group was accompanied by significantly lower numbers of $\mathrm{CD}^{+}{ }^{+} \mathrm{DC}(P=0.008)$, and HLA-DR expression $(P=0.028)$ in the bronchial mucosa than in the bronchodilator-treated group.

Conclusion Our data suggest that dendritic cells are involved in asthmatic inflammation and that corticosteroids may downregulate the number of dendritic.
\end{abstract}

Keywords: dendritic cells, antigen presentation, atopic asthma, inhaled corticosteroids

Clinical and Experimental Allergy, Vol. 26, pp. 517-524. Submitted 16 January 1995; revised 10 April 1995; accepted 8 May 1995.

\section{Introduction}

Atopic asthma is associated with a chronic T-cell-

Correspondence: Dr G.M. Möller, Department of Immunology, Erasmus University, PO Box 1738, 3000 DR Rotterdam, The Netherlands.

(C) 1996 Blackwell Science Ltd mediated inflammatory process in the airways [1-3]. Antigen-presenting cells (APC) play an essential role in asthma since T lymphocytes cannot respond to antigens without the help of APC [4]. Dendritic cells (DC) are the most potent $\mathrm{APC}$ and in contrast to other $\mathrm{APC}$ unique in their capacity to stimulate naive T cells $[5,6]$. Therefore, 
they may play a key role in the initiation of immune responses. In the lung, dendritic cells are predominantly observed in epithelial and subepithelial tissue of the bronch(iol)us and in the bronchus-associated lymphoid tissue [7]. Typical immunohistological features of DC are a strong major histocompatibility complex (MHC) class II(HLA-DR) expression [8-10], long cytoplasmic extensions, and the absence or a juxtanuclear spot of acid phosphatase. A combination of dendritic morphology and the expression of CDla is characteristic for DC $[11,12]$. Increased numbers of $\mathrm{CDla}^{+} \mathrm{DC}$ and increased expression of MHC class II have been described in bronchial biopsies of asthmatic patients [13].

Corticosteroids are the most effective therapy for asthma, but their precise mechanism of action is still unclear [14]. Corticosteroids inhibit cytokine gene transcription and cytokine effects, thereby reducing chronic inflammation in asthma [14-17]. To date, the effects of inhaled corticosteroids on DC in asthma are unknown. We hypothesized that the beneficial effects of corticosteroid therapy in atopic asthmatics may in part result from a downregulation of the numbers of DC, resulting in a decreased local $\mathrm{T}$-cell stimulation. Therefore we examined the distribution of the DC in the bronchial epithelium and mucosa of atopic asthmatics by immunohistochemistry. To this aim the effects of 2.5 years of double-blind treatment with bronchodilators alone or with bronchodilators plus beclomethasone dipropionate (BDP) were evaluated. The patients were randomly sampled from the Dutch chronic non-specific lung disease (CNSLD) study [18].

\section{Materials and methods}

\section{Patients and control subjects}

Sixteen non-smoking atopic asthmatic patients (seven women, nine men, median age 43 years, range $24-61$ years) were randomly sampled from the Dutch CNSLD study group $[18,19]$ in two participating centres, Groningen and Rotterdam.

The diagnosis of asthma was based on a history of attacks of breathlessness and wheezing without chronic cough or sputum production (i.e. for more than 3 months per year),according to the criteria of the American Thoracic Society [20]. Atopy was defined as a positive skin-prick test to house dust mite or at least two of 12 common aeroallergens (mean weal size $>0.7$ times the histamine weal size [21]). All patients showed airway hyperreactivity to histamine with a provocative concentration of histamine causing a $20 \%$ decrease in $\mathrm{FEV}_{1}\left(\mathrm{PC}_{20}\right)$ of $\leqslant 8 \mathrm{mg} / \mathrm{mL}[19,21]$. Patients were treated in a double-blind fashion with an inhaled $\beta_{2}$-agonist (terbutaline, $250 \mu \mathrm{g}$ two puffs) plus either inhaled corticosteroid (BDP, $100 \mu \mathrm{g}$ two puffs) (BA $+\mathrm{CS})(n=5)$, an anticholinergic bronchodilator (ipratropium bromide, $20 \mu \mathrm{g}$ two puffs) (BA + AC) $(n=5)$ or placebo $(\mathrm{BA}+\mathrm{PL})(n=6)$. All medication was taken four times daily. Because no significant differences were found between the $\mathrm{BA}+\mathrm{AC}$ group and the $\mathrm{BA}+\mathrm{PL}$ group with regard to $\mathrm{FEV}_{1}$ and $\mathrm{PC}_{20}$ the data were subsequently pooled for analysis in one bronchodilator group $(n=11)$. The fibreoptic bronchoscopy was performed at the end of the 2.5 years study in the same period (between August and December) in both centres, before breaking the code. Eight healthy non-smoking subjects (three women, five men, median age 23 years, range 19-52 years) without medication were studied as controls. All controls had a $\mathrm{PC}_{20}$ of more than $8 \mathrm{mg} / \mathrm{mL}$ and a median $\mathrm{FEV}_{1}$ of $103(88-110) \%$ predicted. Patient and control characteristics are shown in Table 1. Further details of the study methods have been described previously [19]. The study protocol was approved by the Medical Ethics Committee; all patients and controls gave written informed consent.

\section{Bronchoscopy}

Fibreoptic bronchoscopy ( Olympus model BF IT 10, Tokyo, Japan) was performed with atropine $0.5 \mathrm{mg}$ intramuscularly as premedication. Terbutaline, two puffs of $250 \mu \mathrm{g}$ per Nebuhaler, was given $30 \mathrm{~min}$ before the procedure. The nose, throat and vocal cords were anaesthetized with topical lidocaine spray. An Olympus alligator forceps model FB15C and the fenestrated forceps model FB19C were used to take two biopsies from segmental and subsegmental divisions of the main bronchi.

\section{Bronchial biopsies}

Each biopsy was immediately placed in isotonic saline and frozen within $20 \mathrm{~min}$ in Tissue-Tek II OCT embedding medium (Miles, Naperville, Illinois, USA). Samples were stored at $-80^{\circ} \mathrm{C}$ until use. Frozen sections $(6 \mu \mathrm{m})$ were cut on a Reichert-Jung 2800 Frigocut cryostat. Two sections from each biopsy were placed on poly-L-lysinecoated (Sigma Diagnostics, St Louis, MO, USA) microscopic slides. Sections were air dried for $30 \mathrm{~min}$ and stored at $-80^{\circ} \mathrm{C}$ until use.

\section{Immunohistochemistry}

The following monoclonal antibodies $(\mathrm{MoAb})$ were used: OKT6 (CD1a) (American Type Culture Collection, Rockville, Maryland, USA), directed against the CD1a 
Table 1. Patient and control subject characteristics

\begin{tabular}{|c|c|c|c|c|c|c|}
\hline $\begin{array}{l}\text { Patient } \\
\text { no. }\end{array}$ & Sex & Age (year) & $\begin{array}{l}\text { Baseline } \mathrm{FEV}_{1} \\
\% \text { predicted }\end{array}$ & $\begin{array}{c}\text { After } 2.5 \text { years } \\
\text { FEV }_{1} \\
\% \text { predicted }\end{array}$ & $\begin{array}{c}\text { Baseline } \mathrm{PC}_{20} \\
\mathrm{mg} / \mathrm{mL}\end{array}$ & $\begin{array}{c}\text { After } 2.5 \text { years } \\
\text { PC }_{20} \\
\mathrm{mg} / \mathrm{mL}\end{array}$ \\
\hline \multicolumn{7}{|c|}{ Corticosteroid group } \\
\hline 1 & $\mathrm{~F}$ & 32 & 51.8 & 56.4 & 0.17 & 0.10 \\
\hline 2 & $\mathrm{M}$ & 61 & 84.0 & 98.7 & 0.94 & 5.38 \\
\hline 3 & $\mathrm{~F}$ & 44 & 75.0 & 88.5 & 0.06 & 0.45 \\
\hline 4 & $\mathrm{~F}$ & 60 & 59.7 & 90.3 & 0.06 & 0.96 \\
\hline 5 & $\mathrm{~F}$ & 45 & 49.2 & 69.6 & 0.05 & 0.21 \\
\hline Median & & 45 & 59.7 & 88.5 & 0.06 & 0.45 \\
\hline \multicolumn{7}{|c|}{ Bronchodilator group } \\
\hline 1 & $\mathrm{M}$ & 32 & 70.4 & 51.7 & 0.79 & 0.13 \\
\hline 2 & M & 38 & 48.6 & 31.2 & 0.03 & 0.01 \\
\hline 3 & $\mathrm{~F}$ & 43 & 54.3 & 53.4 & 0.03 & 0.04 \\
\hline 4 & M & 44 & 63.5 & 66.3 & 0.02 & 0.05 \\
\hline 5 & $\mathrm{M}$ & 24 & 61.5 & 54.7 & 0.19 & 0.58 \\
\hline 6 & $\mathrm{M}$ & 50 & 65.1 & 62.7 & 0.28 & 0.18 \\
\hline 7 & M & 57 & 81.6 & 42.3 & 0.14 & 0.04 \\
\hline 8 & $\mathrm{~F}$ & 30 & 100.0 & 96.4 & 4.72 & 0.42 \\
\hline 9 & $\mathbf{M}$ & 26 & 38.3 & 60.0 & 0.24 & 0.40 \\
\hline 10 & M & 42 & 48.7 & 56.5 & 0.24 & 0.87 \\
\hline 11 & $\mathrm{~F}$ & 38 & 57.0 & 43.6 & 0.13 & 0.06 \\
\hline Median & & 38 & 61.5 & 54.7 & 0.19 & 0.13 \\
\hline \multicolumn{7}{|c|}{ Control subjects } \\
\hline 1 & M & 19 & 102 & & & \\
\hline 2 & M & 23 & 109 & & & \\
\hline 3 & $\mathrm{M}$ & 23 & 109 & & & \\
\hline 4 & $\mathrm{~F}$ & 24 & 103 & & & \\
\hline 5 & $\mathrm{~F}$ & 23 & 96 & & & \\
\hline 6 & $\mathrm{M}$ & 23 & 88 & & & \\
\hline 7 & $\mathrm{M}$ & 52 & 88 & & & \\
\hline 8 & $\mathrm{~F}$ & 35 & 110 & & & \\
\hline Median & & 23 & 103 & & & \\
\hline
\end{tabular}

antigen of DC [12]; L25, a MoAb directed against B cells and DC [13] was kindly provided by Dr T. Takami (Gifu, Japan); HLA-DR ( Central Laboratory of the Netherlands Red Cross Blood Transfusion Service (CLB), Amsterdam, the Netherlands), and biotin-conjugated HLA-DR MoAb (Becton Dickinson, San Jose, CA, USA). The MoAb staining was detected by the immuno-alkaline phosphatase anti-alkaline phosphatase (APAAP) method. The sections were fixed in acetone for $10 \mathrm{~min}$ at $20^{\circ} \mathrm{C}$, rinsed in phosphate-buffered saline (PBS, pH 7.2) and placed in a half-automatic stainer (Shandon, Pittsburgh, PA, USA). In this stainer the slides were sequentially incubated with bovine serum albumin (BSA) $2 \%$ in PBS for $10 \mathrm{~min}$, incubated with normal rabbit serum (CLB, Amsterdam, the Netherlands) for $10 \mathrm{~min}$ and incubated with the MoAb in the optimal dilution for $30 \mathrm{~min}$ at $20^{\circ} \mathrm{C}$. The optimal dilutions were determined by previous titration studies of the specific MoAb (OKT6 $10 \mu \mathrm{g} / \mathrm{mL} ; \mathrm{L} 251 \mu \mathrm{g} / \mathrm{mL}$ and HLA-DR $0.1 \mu \mathrm{g} / \mathrm{mL}$ ). The sections were subsequently rinsed in PBS for $5 \mathrm{~min}$ and incubated for $30 \mathrm{~min}$ with a rabbit anti-mouse (RaM) (1:20) immunoglobulin antiserum, rinsed in PBS, incubated with APAAP (1:40) (Dakopatts, Glostrup, Denmark) for $30 \mathrm{~min}$ at $20^{\circ} \mathrm{C}$, rinsed in PBS and TRIS buffer (pH 8.0), and incubated for $30 \mathrm{~min}$ with New Fuchsin substrate (Chroma, Stuttgart, Germany), which stained positive cells red. Finally, the sections were rinsed with distilled water, counter- 
stained with Mayer's haematoxylin, and mounted in glycerin gelatin. Control staining was performed by substitution with PBS and incubation with an irrelevant $\mathrm{MoAb}$ of the same isotype and concentration.

To establish that $\mathrm{L}_{25}{ }^{+}$DC were also expressing HLADR we performed a double-labelling with L25 and biotinylated HLA-DR. The procedure followed the APAAP protocol up to the incubation with APAAP for $30 \mathrm{~min}$. After rinsing in PBS and blocking with normal mouse serum $(1: 10)$ for $10 \mathrm{~min}$, the slides were incubated for $45 \mathrm{~min}$ with the second MoAb biotinylated HLA-DR. Slides were rinsed in PBS and incubated with streptavidine $-\beta$ galactosidase (Biogenex, San Ramon, CA, USA) for $45 \mathrm{~min}$, and rinsed again with PBS. Slides were sequentially incubated with $\beta$ galactoside (Serva, Heidelberg, Germany) which stained positive cells green, rinsed in TRIS buffer $(\mathrm{pH} \mathrm{8.0)}$ and stained with New Fuchsin, which stained $\mathrm{L}_{2} 5^{+}$cells red. Finally, the sections were rinsed in distilled water and mounted in glycerin gelatin. The immuno-double staining with L25 and HLA-DR was performed on three sections of three different patients, because of scarcity of biopsy material.

\section{Quantification}

Biopsies were coded and two sections $120 \mu$ m apart were counted in a blinded fashion for each antibody and each biopsy at a magnification of $10 \times 40$ by one person (G.M.M.) and the mean value was calculated. With an eye piece graticule the numbers of positively stained cells were counted in a zone $100 \mu \mathrm{m}$ deep in the bronchial mucosa along the length of the epithelial basement membrane (BM), which had to be covered with epithelium over at least $500 \mu \mathrm{m}$. Cells were counted if they stained red and contained a nucleus. The cell counts were expressed as the number per unit $(1 \mathrm{~mm})$ of basement membrane. The (biotinylated) HLA-DR expression was scored semiquantitatively on a $0-3$ scale $(0=$ negative; 1 =weak; 2 =strong; 3 =very strong). Double-stained cells $\mathrm{L}_{2} 5^{+}$and biotinylated HLA-DR ${ }^{+}$were counted if they stained violet and contained a nucleus.

\section{Statistical analysis}

The numbers of positive cells for most of the MoAb used showed a positive skewed distribution and therefore were analysed using non-parametric statistics. Median cell counts from biopsies from asthmatics who received inhaled corticosteroids were compared with those who received only bronchodilators using the Mann-Whitney $U$-test. Median cell counts from biopsies from atopic asthmatics of the bronchodilator group were compared with median cell counts of the control subjects using the
Table 2. Pulmonary function data of the patients included in the study

\begin{tabular}{lccc}
\hline & $\begin{array}{c}\text { Corticosteroid } \\
\text { group }\end{array}$ & $\begin{array}{c}\text { Bronchodilator } \\
\text { group }\end{array}$ & $P$-value \\
\hline$\Delta \mathrm{FEV}_{1}$ & $14.7(4.6-30.6)$ & $-3.6(-39.3-21.7)$ & 0.009 \\
$\Delta \log _{2} \mathrm{PC}_{20}$ & $2.5(-0.8-4.0)$ & $0.6(-3.5-1.9)$ & 0.013 \\
\hline
\end{tabular}

$\triangle \mathrm{FEV}_{1}$ in $\%$ predicted: difference in median change (ranges) of $\mathrm{FEV}_{1} \%$ predicted from baseline to 2.5 years.

$\Delta \log _{2} \mathrm{PC}_{20}$ in $\mathrm{mg} / \mathrm{mL}$ : difference in median change (ranges) of $\log _{2} \mathrm{PC}_{20} \mathrm{mg} / \mathrm{mL}$ to histamine from baseline to 2.5 years.

Mann-Whitney $U$-test. A value of $P<0.05$ was considered significant.

\section{Results}

\section{Pulmonary function data}

Details of patient and pulmonary function data have been described before [18]. In short: $2 \frac{1}{2}$ years of inhaled BDP resulted in a significant improvement in $\mathrm{FEV}_{1}$ of $14.7 \%$ of predicted compared with bronchodilator group $\left(-3.6 \%\right.$ of predicted, $P=0.009$ ) (Table 2). $\log _{2} \mathrm{PC}_{20}$ in the corticosteroid group improved 2.5 dose steps, compared with 0.6 dose steps in the bronchodilator group $(P=0.013)($ Table 2$)$.

\section{Bronchial epithelium}

Some sections could not quantitatively be evaluated for bronchial epithelial infiltration because they did not show enough intact epithelium (Table 3 ). In the sections of the asthmatic patients who received bronchodilators only $(n=7)$ the epithelium consisted for approximately $60 \%$ of a monolayer and for $10 \%$ of a multilayer of partially stratified cuboidal epithelium; the epithelium of the group of corticosteroid-treated patients consisted for approximately $45 \%$ of a monolayer and for $40 \%$ of a multilayer of cuboidal epithelium. The loss of epithelium from the BM (shedding) was $30 \%$ of the total length of epithelium in the bronchodilator group whereas it was $15 \%$ in the corticosteroid group.

Though there were clearly dendritic-shaped $\mathrm{CDla}{ }^{+}$ cells expressing MHC class II in the epithelium of all the groups studied, differences between groups did not reach statistical significance (Table 3 ).

\section{Bronchial mucosa}

The bronchial mucosa of the asthmatic patients consisted of a subepithelial cell-rich layer and a deeper cell 
Table 3. Median cell counts (ranges) in bronchial epithelium and mucosa in atopic asthmatics after 2.5 yrs treatment and in control subjects per mm of basement membrane

\begin{tabular}{|c|c|c|c|c|c|}
\hline & Corticosteroid group & Bronchodilator group & Control subjects & ${ }^{*} P$-value & ${ }^{*} P$-value \\
\hline \multicolumn{6}{|c|}{ Bronchial epithelium } \\
\hline $\mathrm{CD} \mathrm{a}^{+} \mathrm{DC}$ & $\begin{array}{l}0(0) \\
n=4\end{array}$ & $\begin{array}{c}0.4(0-5.3) \\
n=10\end{array}$ & $\begin{array}{c}0(0-3.6) \\
n=7\end{array}$ & 0.106 & 0.601 \\
\hline $\mathrm{L} 25^{+}$cells & $\begin{array}{c}2.5(0-10.4) \\
n=4\end{array}$ & $\begin{array}{c}0.5(0-9.6) \\
n=8\end{array}$ & $\begin{array}{c}1.0(0-3.2) \\
n=5\end{array}$ & 0.461 & 1 \\
\hline HLA-DR & $\begin{array}{c}0(0-3.0) \\
n=5\end{array}$ & $\begin{array}{c}1(0-2.0) \\
n=10\end{array}$ & $\begin{array}{c}1(0-2.0) \\
n=6\end{array}$ & 0.594 & 0.635 \\
\hline \multicolumn{6}{|c|}{ Bronchial тисоsа } \\
\hline $\mathrm{CD}^{\mathrm{a}} \mathrm{a}^{+} \mathrm{DC}$ & $\begin{array}{c}0.7(0-1.4) \\
n=4\end{array}$ & $\begin{array}{c}2.5(1.1-6.7) \\
n=10\end{array}$ & $\begin{array}{c}0(0-4.0) \\
n=7\end{array}$ & 0.008 & 0.003 \\
\hline $\mathrm{L} 25^{+}$cells & $\begin{array}{c}5.7(1.6-16.3) \\
n=4\end{array}$ & $\begin{array}{c}10.3(6.7-13.6) \\
n=8\end{array}$ & $\begin{array}{c}0.5(0-1.7) \\
n=5\end{array}$ & 0.282 & 0.002 \\
\hline HLA-DR & $\begin{array}{c}1.0(0-2.0) \\
n=5\end{array}$ & $\begin{array}{c}2.0(0-3.0) \\
n=10\end{array}$ & $\begin{array}{c}1.5(1.0-2.0) \\
n=6\end{array}$ & 0.028 & 0.042 \\
\hline
\end{tabular}

†Median score (ranges).

${ }^{*} P$ Corticosteroid group compared with bronchodilator group.

${ }^{* *} P$ Bronchodilator group compared with controls.

poor layer. Higher numbers of $\mathrm{CDla}^{+} \mathrm{DC}$ were found in the bronchial mucosa of patients of the bronchodilator group $(P=0.008)$ (Fig. 1). In addition, the numbers of $\mathrm{L} 25^{+}$cells (Figs 1 and 2 ) and the expression of MHC class II (Fig. 1) in the bronchodilator group were higher than in the healthy controls (Table 3). The doublestaining of HLA-DR and L25 showed that virtually all L25 ${ }^{+}$DC expressed HLA-DR. The HLA-DR expression was not only confined to cells in the mucosa showing an irregular outline with marked cytoplasmic extensions (DC), but there were also other cells like lymphocytes and macrophages positive for HLA-DR.

The numbers of CDla ${ }^{+}$DC were significantly lower in the corticosteroid-treated group than in the bronchodilator group $(P=0.008)$ (Fig. 1). The number of $\mathrm{L} 25^{+}$ cells in the corticosteroid group was also lower (median $5.7 / \mathrm{mmBM}$ ) than in the bronchodilator group (median $10.3 / \mathrm{mmBM})$, but this difference did not reach significance $(P=0.282)$ (Table 3$)$. However, a significantly lower MHC class II expression was found in the corticosteroid group compared with the bronchodilator group (Fig. 1) $(P=0.028)$.

\section{Discussion}

In this study we have observed that the numbers of DC in the bronchial mucosa of atopic asthmatic patients are significantly higher than in healthy control subjects and that 2.5 years of inhaled corticosteroid therapy downregulate the number of DC to normal levels, accompanied by a significantly improved $\mathrm{FEV}_{1}$ and reduced hyperresponsiveness.

Our data of increased numbers of $\mathrm{CDla}^{+} \mathrm{DC}$ in atopic asthma are in agreement with data of a study of Bellini et al. [22] who also showed increased numbers of intraepithelial and mucosal CD1 ${ }^{+}$DC in atopic asthmatics as compared to non-asthmatic atopic controls sensitized to the same allergen. Furthermore, an increased frequency of DC has been reported in the nasal mucosa of patients with atopic rhinitis during the pollen season [23].

Dendritic cells in the epithelium of the airways form a network $[24,25]$. For primary responses they are strategically positioned to pick up inhaled antigens, migrate to regional lymph nodes and present the inhaled antigens to lymphnode $\mathrm{T}$ cells. For secondary responses in the mucosa local antigen presentation by $\mathrm{DC}$ to $\mathrm{T}$ cells and local activation of $\mathrm{T}$ cells are thought to occur as well [26]. In asthma it has been suggested that DC play a prime role in inducing cytokine production by the local activation of $T$ cells $[27,28]$. In this way they are thought to act as important pro-inflammatory cells. It has indeed been demonstrated both in vivo [29] as well as in vitro $[22,30]$ that $\mathrm{DC}$ are able to activate $\mathrm{TH}_{2}$ cells. The mechanisms by which DC induce the expansion of $\mathrm{TH}_{2}$ cells are still unclear, but some consider - despite the low production of cytokines by DC - the secretion of 

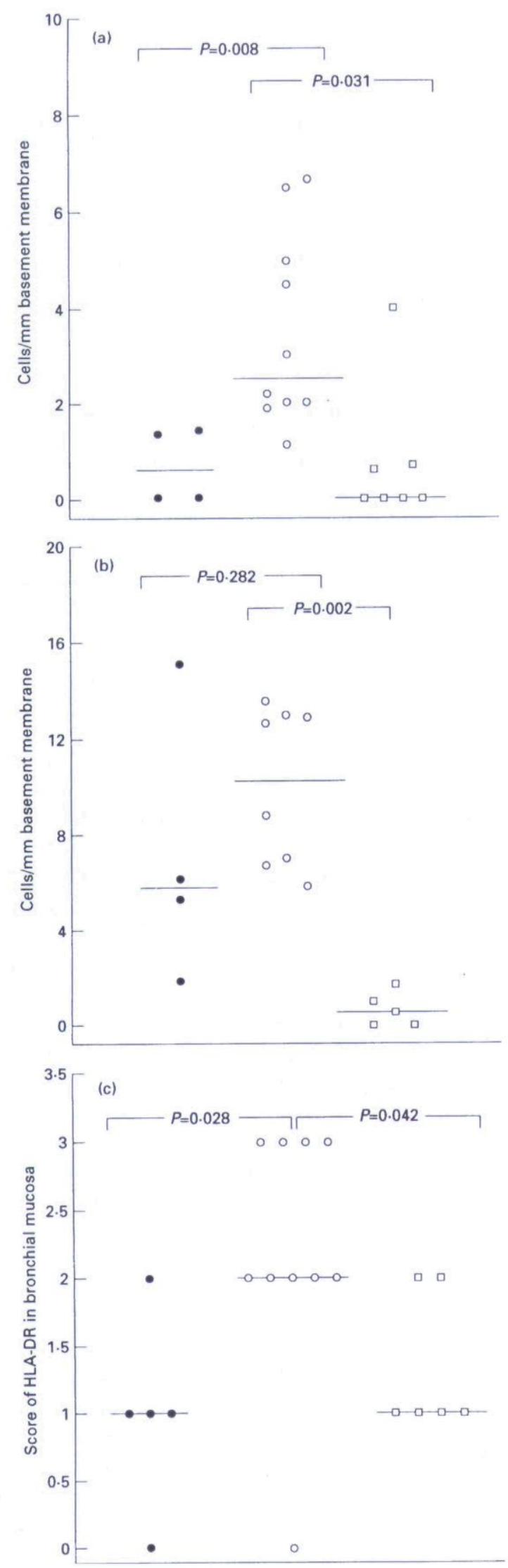

interleukin-1, a co-stimulator for $\mathrm{TH}_{2}$ cells, as important. DC might, however, also induce $\mathrm{TH}_{1}$ expansion [31]. In vitro IL-12 production by DC favours such TH-1 expansion, as observed by secretion of interferon-gamma $(\operatorname{IFN} \gamma)$ and immunoglobulin $\mathrm{G}_{2 \mathrm{a}}\left(\operatorname{IgG}_{2 \mathrm{a}}\right)$ humoral responses [32].

Biopsy studies in patients with asthma have confirmed that inhaled corticosteroids reduce the number and activation of several inflammatory cells [33-36]. Although this study was carried out on a limited number of patients, our data show that clinical improvement induced by local BDP administration is accompanied by significantly lower numbers of $\mathrm{CDla}^{+} \mathrm{DC}$ and HLA-DR $^{+}$cells in the bronchial mucosa. The here described inhibitory effects of 2.5 years of corticosteroids on DC numbers and HLA-DR expression, are in agreement with data of Burke et al. who described a reduction in $\mathrm{RFD} 1^{+} \mathrm{DC}$ and HLA-DR expression after 3 months of budesonide in asthma [13]. Thus, long-term treatment with inhaled corticosteroids also reduces the number of DC in the bronchial mucosa. Studies in the nasal mucosa of patients with atopic rhinitis showed that 3 months of fluticasone therapy decreases the $\mathrm{CDla}^{+}$and HLA$\mathrm{DR}^{+}$cells [37].

It may be that chemoattractive factors such as leukotriene B4 [38], monocyte chemoattractant protein 1 [39], and substance $\mathrm{P}$ play a role in attracting DC into the epithelium in allergic inflammation. Substance $P$, secreted by C-fibres was found to be a highly effective chemoattractant for DC [40] and in this way neurogenic inflammation might contribute to the DC migration. Interestingly, corticosteroids have been reported to suppress the release of chemotactic factors from epithelial cells, indicating a possible important role of the epithelium in DC kinetics [38] under such circumstances.

In conclusion, our data show that DC numbers are elevated in atopic asthma, and can be normalized by local corticosteroid therapy. We suggest that DC may play an important role in the initiation and propagation of the asthmatic inflammation because DC are situated strategically in bronchial mucosa and DC have been described as the most potent APC population for T-cell stimulation. In this way, reduction of DC numbers after 2.5 years of corticosteroid therapy may result in a down-

Fig. 1. Individual counts for cells expressing (a) $\mathrm{CDla}^{+} \mathrm{DC}$ and (b) $\mathrm{L}_{2} 5^{+} \mathrm{DC}$ in the bronchial mucosa, expressed as the number of positive cells $/ \mathrm{mm}$ basement membrane and individual score of (c) HLA-DR expression in the bronchial mucosa. Median values are represented by the horizontal bars. Corticosteroid. O. Bronchodilator. $\square$ Control subjects. 


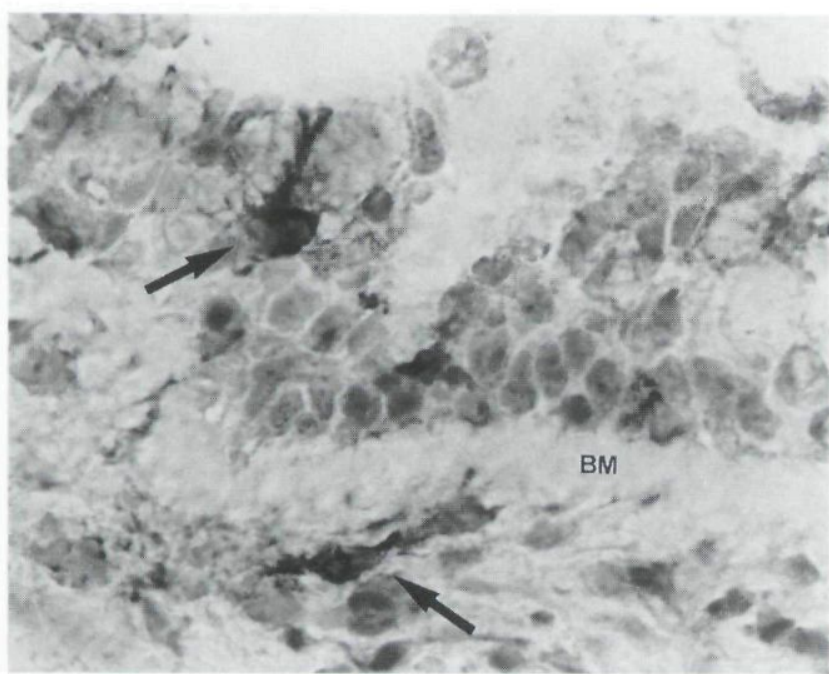

Fig. 2. Cryostat section of a bronchial mucosal biopsy of an asthmatic patient. $\mathrm{L}_{2}{ }^{+}$dendritic-shaped cells in the bronchial epithelium and mucosa, situated just under the BM (arrows).

regulation of T-cell activation and hence affect allergic airway inflammation.

\section{Acknowledgements}

We are grateful to Professor Dr R. Benner for his continuous support. We thank Professor Dr H. A. Drexhage for critically reading this manuscript. We thank Dr R. Aalbers for taking biopsies, Mr T.M. van Os for photographical assistance, Mrs M. Smith for technical assistance and Mrs. P. Assems for secretarial assistance. This study was financially supported by Glaxo, Zeist, the Netherlands.

\section{References}

1 Corrigan CJ, Kay AB. T cells and eosinophils in the pathogenesis of asthma. Immunol Today 1992; 13:12:501-7.

2 Poulter LW, Janossy G, Power C, Sreenan S, Burke C. Immunological/physiological relationships in asthma: potential regulation by lung macrophages. Immunol Today 1994; 15:6:258-61.

3 Gavett SH, Chen X, Finkelman F, Wills-Karp M. Depletion of murine $\mathrm{CD}^{+} \mathrm{T}$ lymphocytes prevents antigeninduced airway hyperreactivity and pulmonary eosinophilia. Am J Respir Cell Mol Biol 1994; 10:587-93.

4 Davis MM, Bjorkman BJ. T-cell antigen receptor genes and T-cell recognition. Nature 1988; 334:395-402.

5 Inaba K, Steinmann RM. Resting and sensitized T lymphocytes exhibit distinct stimualting (antigen-presenting cell) requirements for growth and lymphokine release. J Exp Med 1984; 160:1717-35.
6 Steinmann RM. The dendritic cell system and its role in immunogenicity. Ann Rev Immunol 1991; 9:271-96.

7 Van Haarst JMW, Wit HJ de, Drexhage HA, Hoogsteden HC. Distribution and immunophenotype of mononuclear phagocytes and dendritic cells in the human lung. Am J Respir Cell Mol Biol 1994; 10:487-92.

8 Van Voorhis WC, Hair LS, Steinmann RM, Kaplan G. Human dendritic cells, enrichment and purification from peripheral blood. J Exp Med 1982; 155:1172-87.

9 Schon-Hegrad MA, Oliver J, McMenamin PG, Holt PG. Studies on the density, distribution, and surface phenotype of intraepithelial class II major histocompatability complex antigen (1a) - bearing dendritic cells (DC) in the conducting airways. J Exp Med 1991; 173:1345-56.

10 Melief CJM. Dendritic cells are specialized antigen-presenting cells. Res Immunol 1989; 140:902-6.

11 Murphy G, Bhan A, Sato S, Mihm M, Harrist T. A new immunologic marker for epidermal Langerhans cells. N Engl J Med 1981; 304:791-2.

12 Ishii Y, Takami T, Kokai Y et al. A novel human B cell antigen shared with lymphoid dendritic cells: characterization by a monoclonal antibody. Clin Exp Immunol 1985; 61:624-32.

13 Burke C, Power CK, Norris A et al. Lung function and immunopathological changes after inhaled corticosteroids therapy in asthma. Eur Respir J 1992; 5:73-9.

14 Barnes PJ, Pedersen S. Efficacy and safety of inhaled corticosteroids in asthma. Am Rev Respir Dis 1993; 148:S1-S26.

15 Corrigan CJ, Hackzu A, Gemou-Engesaeth V, Doi S, Kikuchi Y, Takatsu S, Durham SR, Kay AB. CD4-T lymphocyte activation in asthma is accompanied by increased serum concentrations of interleukin-5. Am Rev Respir Dis 1993; 147:540-7.

16 Borish L, Mascali JJ, Dishuck J et al. Detection of alveolar macrophage-derived IL-1 $\beta$ in asthma. Inhibition with corticosteroids. J Immunol 1992; 149:3078-82.

17 Robinson D, Hamid Q, Sun Ying et al. Prednisolon treatment in asthma is associated with modulation of bronchoalveolar lavage cell interleukin-4, interleukin-5, and interferon- $\gamma$ cytokine gene expression. Am Rev Respir Dis 1993; 148:401-6.

18 Kerstjens HAM, Brand PLP, Hughes MD et al. and the Dutch CNSLD Study Group. A comparison of bronchodilator therapy with or without inhaled corticosteroid therapy for obstructive airways disease. N Engl J Med 1992; 327:1413-9.

19 Brand PLP, Kerstjens HAM, Postma DS et al. and the Dutch CNSLD study group. Long-term multicentre trial in chronic non-specific lung disease: methodology and baseline assessment in adult patients. Eur Respir J 1992; 5:21-31.

20 ATS Task Group. Standards for the diagnosis and care of patients with chronic obstructive pulmonary disease (COPD) and asthma. Am Rev Respir Dis 1987; 136:225-31.

21 Cockcroft DW, Kilian DN, Mellon JJA, Hargreave FE. Bronchial hyperreactivity to inhaled histamine: a method and clinical survey. Clin Allergy 1977; 7:235-43. 
22 Bellini A, Vittori E, Marini M, Ackerman V, Mattoli S. Intraepithelial dendritic cells and selective activation of Th2-like lymphocytes in patients with atopic asthma. Chest 1993; 103:997-1005.

23 Fokkens WY. CD-1 (T6), HLA-DR-expressing cells, presumably Langerhans' cells, in nasal mucosa. Allergy 1989; 44:167-72.

24 Holt PG. Regulation of antigen-presenting cell function(s) in lung and airway tissues. Eur Respir J 1993; 6:120-9.

25 Holt PG, Schon-Hegrad MA, Phillips MJ, McMenamin PG. Ia-positive dendritic cells form a tightly meshed network within the human airway epithelium. Clin Exp Allergy 1989; 19:597-601.

26 Sertl K, Takemura TT, Tschachler E et al. Dendritic cells with antigen presenting capability reside in airway epithelium, lung parenchyma and visceral pleura. J Exp Med $1986 ; 163: 436-51$.

27 Hamid Q, Azzawi M, Sun Ying et al. Expression of mRNA for interleukin-5 in mucosal biopsies from asthma. J Clin Invest $1991 ; 87: 1541-6$.

28 Robinson DS, Hamid Q, Sun Ying et al. Predominant Th2like bronchoalveolar T-lymphocyte population in atopic asthma. N Eng J Med 1992; 326:298-304.

29 Simon JC, Cruz PD, Bergstresser PR, Tigelaar RE. Low dose ultraviolet $\beta$-irradiated Langerhans' cells preferentially activate $\mathrm{CD}^{+}$cells of the T-helper 2 subset. J Immunol 1990; 145:2087-91.

30 Hauser C, Snapper J, O'Hara W, Paul W, Katz S. Cultured Langerhans' cells activate type $2 \mathrm{~T}$ helper cells which produce IL-4/BSF1. J Invest Dermatol 1988; 90:A568.

31 Hance AJ. Pulmonary immune cells in health and disease: Dendritic cells and Langerhans' cells. Eur Respir J 1993; 6:1213-20.

32 Caux C, Liu Y, Banchereau J. Recent advances in the study of dendritic cells and follicular dendritic cells. Immunol Today $1995 ; 16: 2-4$.
33 Nicod LP, Galve-de Rochemonteix B, Dayer JM. Dissociation between allogeneic $\mathrm{T}$-cell stimulation and interleukin-1 or tumor necrosis factor production by human lung dendritic cells. Am J Respir Cell Mol Biol 1990; 2:515-22.

34 Djukanovic R, Wilson JW, Britten KM, Wilson SJ, Walls AF, Roche WR, Howarth PH, Holgate ST. Effect of an inhaled corticosteroid on airway inflammation and symptoms in asthma. Am Rev Respir Dis 1992; 145:669-74.

35 Laitinen LA, Laitinen A, Haahtela T. A comparative study of the effects of an inhaled corticosteroid, budesonide, and of a $\mathbf{B}_{2}$-agonist, terbutaline on airway inflammation in newly diagnosed asthma. J Allergy Clin Immunol 1992; 90:32-42.

36 Jeffery PK, Godfrey RW, Ädelroth E, Rogers A, Johansson $\mathrm{S}-\mathrm{A}$. Effects of treatment on airway inflammation and thickening of basement membrane reticular collagen in asthma. A quantitative light and electron microscopic study. Am Rev Respir Dis 1992; 145:890-9.

37 Fokkens W. In The pathogenesis of allergic rhinitis, cellular aspects with special emphasis on Langerhans cells. 1991; PhD Thesis, University of Rotterdam.

38 Koyama S, Rennard SI, Leikauf GD, Robbins RA. Bronchial epithelial cells release monocyte chemotactic activity in response to smoke and endotoxin. J Immunol 1991; 147:972-9.

39 Sousa AR, Lane SJ, Nakhostan JA, Yoshimura T, Lee TH, Poston RN. Increased expression of the monocyte chemoattractant protein-1 in bronchial tissue from asthmatic subjects. Am J Respir Cell Mol Biol. 1994; 10:142-7.

40 Kradin R, Xia W, Pinto C, Zhao L-H. Substance P containing unmyelinated $\mathrm{C}$-fibers are present in immediate proximity to airway dendritic cells and may promote their migration during inflammation. Am Rev Respir Dis 1994; 149:A267. 
This document is a scanned copy of a printed document. No warranty is given about the accuracy of the copy. Users should refer to the original published version of the material. 